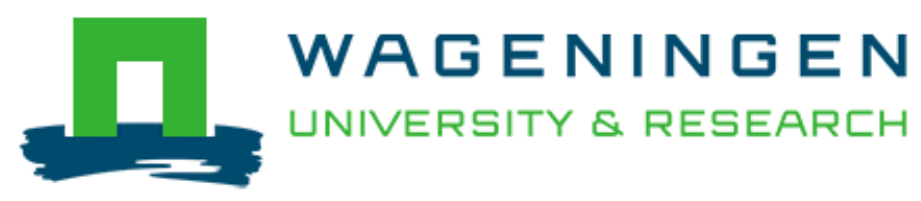

Stomach contents and stable isotopes confirm ontogenetic diet shifts of Nile perch, Lates niloticus, in southern Lake Victoria

Cornelissen, I. J. M., Vijverberg, J., van den Beld, A. M., Helmsing, N. R., Verreth, J. A. J., \& Nagelkerke, L. A. J.

This is a "Post-Print" accepted manuscript, which has been published in "Journal of Great Lakes Research"

This version is distributed under a non-commercial no derivatives Creative Commons (c) (1) $\$(9$ reproduction in any medium, provided the original work is properly cited and not used for commercial purposes. Further, the restriction applies that if you remix, transform, or build upon the material, you may not distribute the modified material.

Please cite this publication as follows:

Cornelissen, I. J. M., Vijverberg, J., van den Beld, A. M., Helmsing, N. R., Verreth, J. A. J., \& Nagelkerke, L. A. J. (2018). Stomach contents and stable isotopes confirm ontogenetic diet shifts of Nile perch, Lates niloticus, in southern Lake Victoria.

Journal of Great Lakes Research, 44(6), 1264-1272.

https://doi.org/10.1016/j.jglr.2018.08.008 


\section{Stomach contents and stable isotopes confirm ontogenetic diet shifts of Nile perch, Lates niloticus, in southern Lake Victoria}

I.J.M. Cornelissen ${ }^{\mathrm{a}, \mathrm{b}, *}$, J. Vijverberg ${ }^{\mathrm{b}}$, A.M. van den Beld ${ }^{\mathrm{b}, 1}$, N.R. Helmsing ${ }^{\mathrm{b}}$, J.A.J. Verreth ${ }^{\mathrm{a}}$, L.A.J. Nagelkerke ${ }^{\mathrm{a}}$

a Wageningen University \& Research, Aquaculture and Fisheries Group, P.O. Box 338, 6700 AH Wageningen, the Netherlands

${ }^{\mathrm{b}}$ Netherlands Institute of Ecology (NIOO-KNAW), P.O. Box 50, 6700 AB, Wageningen, the Netherlands

${ }^{1}$ Present address: Trading Company Cocoanect BV, 3016 CL, Westerkade 2-B, Rotterdam, the Netherlands

*Ilse Cornelissen, Wageningen University \& Research, Aquaculture and Fisheries Group, P.O. Box 338, 6700 AH

Wageningen, the Netherlands. E-mail: Ilsecornelissen@hotmail.com. Tel: +31 621266559.

Communicated by Harvey Bootsma

Published as: Cornelissen, I.J.M., et al., Stomach contents and stable isotopes confirm ontogenetic diet shifts of Nile perch, Lates niloticus, in southern Lake Victoria, J. Great Lakes Res. (2018),

https://doi.org/10.1016/j.jglr.2018.08.008 


\begin{abstract}
Nile perch (Lates niloticus), a main target for Lake Victoria's fisheries, shifts its diet from invertebrates to fish during its ontogeny. We combined stomach contents with stable isotopes to study these diet shifts in Mwanza Gulf, southern Lake Victoria. During four seasons between 2009 and 2011 we collected and analysed 6697 stomachs and 516 stable isotope samples of Nile perch. Caridina shrimp and haplochromine cichlids were the major food items in Nile perch of 5-40 cm. Based on stomach contents, the shift of dominance of Caridina towards haplochromines in the diet varied from $6.7 \mathrm{~cm}$ in the southern part of the gulf, to $\geq 20 \mathrm{~cm}$ in the northern part, possibly related to the higher abundance of Caridina in the north. In general isotope-based and stomach-content-based estimates of Nile perch diets agreed. We observed only two discrepancies: in Nile perch $>20 \mathrm{~cm}$, the isotope-based estimates of the contribution of haplochromines to the diet were much lower than based on stomach contents and the contribution of juvenile Nile perch to the diet were much higher in the isotope-based estimates than in the stomach based-based estimates. This discrepancy may be explained by e.g. different timespan-coverages between isotopes and stomach contents, by movements of Nile perch between the Gulf and the rest of Lake Victoria, or by the overlapping isotopic profiles of haplochromines and juvenile Nile perch. With the recent recovery of haplochromines in Lake Victoria, Nile perch appears to rely more on this prey again, as it did in the 1980s.
\end{abstract}

Keywords: Tropical lake, Fish-food relationships, Haplochromine cichlids, Caridina shrimp, Rastrineobola argentea 


\section{Introduction}

Many fish change their diet when increasing in size. Size-specific diet shifts are related to changes in morphology, prey availability, competition and predation risk (Kimirei et al., 2013; Luczkovich et al., 1995; Wainwright and Richard, 1995; Werner and Gilliam, 1984; Wu and Culver, 1992). When increasing in body size, the subsequent increase in mouth gape allows fish to ingest a larger range of prey types and sizes (Wainwright and Richard, 1995; Werner and Gilliam, 1984). In addition, prey availability may drive or hinder ontogenetic diet shifts in predatory fish (Galarowicz et al., 2006; Garcia-Berthou and Moreno-Amich, 2000). For instance, seasonal fluctuations in zooplankton can induce or delay an ontogenetic diet shift towards larger benthic invertebrates in yellow perch Perca flavescens (Wu and Culver, 1992). Ontogenetic diet shifts may also be related to habitat, which is then often a trade-off between prey availability and predation risk (Werner and Gilliam, 1984). Many fish migrate to more productive habitats with a higher density of predators when they increase in size and become less vulnerable to predation (Cocheret de la Morinière et al., 2003; Kimirei et al., 2013; Nowak et al., 2004).

Nile perch (Lates niloticus) is an opportunistic predator, feeding on a large variety of prey across lakes in East Africa (Dadebo et al., 2005; Gee, 1969; Hamblyn, 1966; Katunzi et al., 2006; Ogutu-Ohwayo, 1990; Schofield and Chapman, 1999). In Lake Victoria, Nile perch $<5 \mathrm{~cm}$ were reported to feed exclusively on zooplankton before ontogenetically switching to macro-invertebrates (Katunzi et al., 2006). The diet composition of Nile perch $>5 \mathrm{~cm}$ is highly variable and shows a clear long-term variation in diet composition (Budeba and Cowx, 2007; Hughes, 1986; Kishe-Machumu et al., 2012; Mkumbo and Ligtvoet, 1992). After its introduction, in the 1950s, Nile perch fed mainly on the dominant haplochromine cichlids (Gee, 1969), but with the decline of haplochromines in the 1980s, it switched to the abundant atyid shrimp Caridina nilotica and fish such as dagaa (Rastrineobola argentea, Cyprinidae) and juvenile Nile perch (Hughes, 1986, 1992; Katunzi et al., 2006; Mkumbo and Ligtvoet, 1992). Since the 1990s, a recovery of haplochromines has been observed in Lake Victoria (Witte et al., 2000, 2007) and haplochromines are an increasingly important prey again for Nile perch (Cornelissen et al., 2015; Kishe-Machumu et al., 2012).

Nile perch usually switches from invertebrates to fish when it grows, but the size at which it shifts its diet is variable (Mkumbo, 2002). In southern Lake Victoria even large-sized Nile perch up (up to $70 \mathrm{~cm}$ ) may feed on Caridina, especially in deeper waters and during the rainy season when Caridina abundances are high, whereas in shallow waters Nile perch feed on haplochromines when Caridina abundances are low (Budeba and Cowx, 2007; Cornelissen et al., 2015; Katunzi et al., 2006).

Previous studies on ontogenetic diet shifts of Nile perch were mainly based on stomach analyses, giving detailed information on the diet composition at the moment the Nile perch was caught (Budeba and Cowx, 2007; Kishe-Machumu et al., 2012; Mkumbo and Ligtvoet, 1992). However, to investigate trophic interactions, stable isotopes are increasingly used, because these reflect the assimilation of prey following ingestion and therefore they include the differences in assimilation efficiencies of the various food types ingested and integrate the dietary intake over a longer time span (Peterson and Fry, 1987). For this reason the isotope method is considered superior to the stomach content analysis method for estimation of a fish's trophic position. However, stomach content data give useful additional information about prey selection. In food-web studies these two methods are complementary and together give a more complete insight in food web interactions (Cocheret de la Morinière et al., 2003; Davis et al., 2012; Dromard et al., 2015; Grey, 2001; Peterson and Fry, 1987).

Ontogenetic diet shifts can be detected by a changing signature of the stable isotopes of both carbon $\left(\delta^{13} \mathrm{C}\right)$ and nitrogen $\left(\delta^{15} \mathrm{~N}\right)$ (Cocheret de la Morinière et al., 2003; Davis et al., 2012; Grey, 2001). The $\delta^{13} \mathrm{C}$ signature remains relatively stable when moving upwards in the food web and reflects the type of carbon source i.e. primary production at the base of the food web, whereas $\delta^{15} \mathrm{~N}$ values increase with each trophic level and reflect the diets of consumers in the food web.

We used stable isotopes and stomach contents to study the ontogenetic diet shift of Nile perch in the Mwanza Gulf, south-east Lake Victoria. We addressed the following questions: How well do diets based on stable isotopes analysis and stomach contents analysis match? At which size does Nile perch ontogenetically shift its diet from Caridina to haplochromines? How do diet shifts vary in time and space? And finally, how can these varying diet shifts be explained? 


\section{Methods}

\section{Study location}

Samples were collected at 6 stations at three regions in the Mwanza Gulf in southern Lake Victoria (Tanzania) (Fig. 1). The Gulf is about $60 \mathrm{~km}$ long, 2.5-11 km wide and 3-25 $\mathrm{m}$ in depth. Region 1 is situated at the southern end of the Gulf and has a depth $<5 \mathrm{~m}$; region 2, which lies more to the north, has a depth range of 5-10 m, and region 3, located at the entrance of the Gulf has a depth range of 15-25 m (Fig. 1). The shoreline at Mwanza City near the entrance of the Gulf is urbanized, while inside the Gulf it is covered by papyrus (Cyperus papyrus), reeds (e.g. Phragmites australis) and water hyacinth (Eichhornia crassipes), alternating with rock formations. The bottom of the Gulf consists of soft mud.

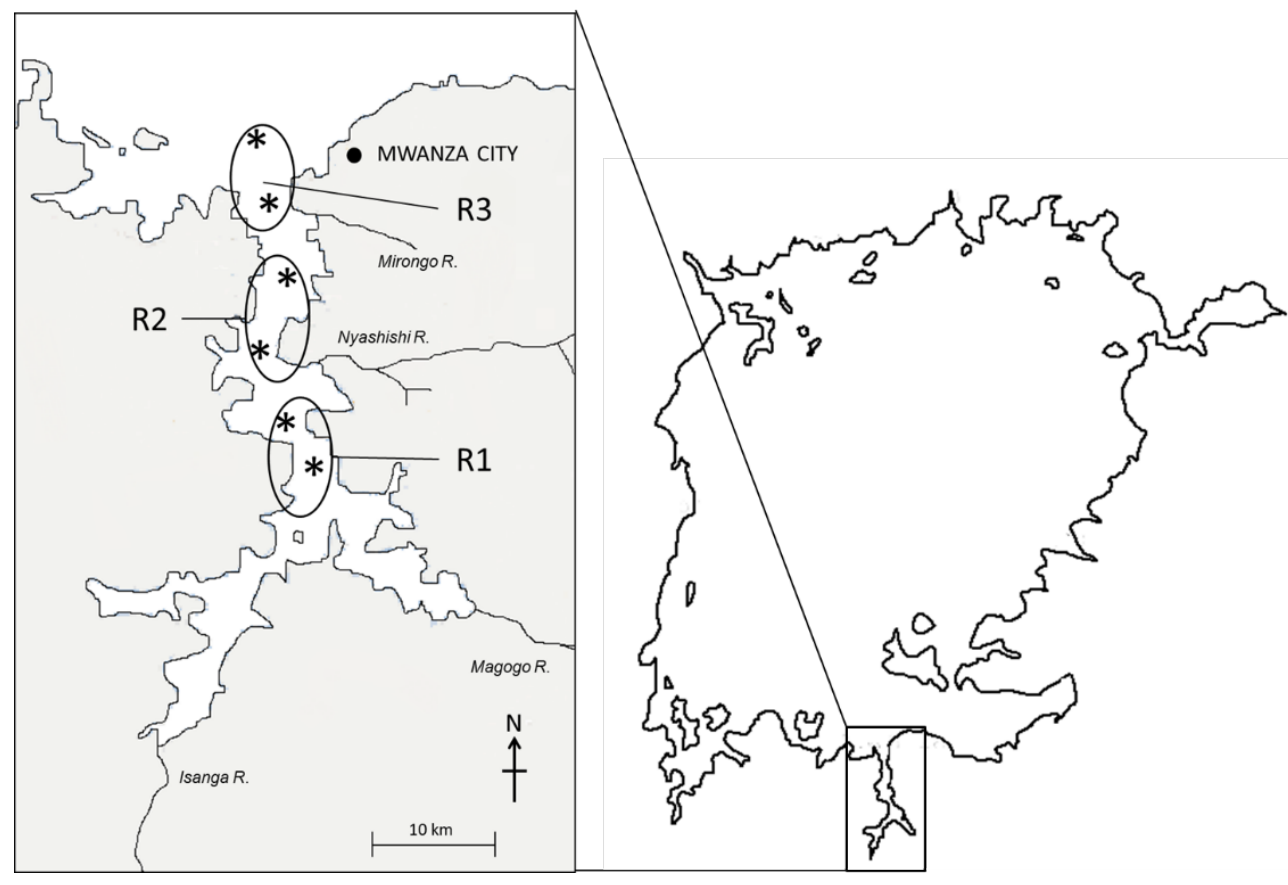

Fig. 1 Lake Victoria and the six sampling stations in three regions in the Mwanza Gulf. Region 1 (R1) has a depth of $<5 \mathrm{~m}$, region 2 (R2) a depth range of 5-10 $\mathrm{m}$ and region 3 (R3) a depth range of 15-25 m.

\section{Climate}

Lake Victoria has a tropical climate based on yearly monsoons. The weather is characterized by three seasons, a dry season, followed by two rainy seasons. Strong winds and low precipitation characterize the dry season, which is from June to August. The water column is well-mixed, isothermal and oxygenated during this season (Akiyama et al., 1977; Talling, 1966). The short rainy season, from September to December, is characterized by increasing rainfall and temperatures, warming up the surface water and gradually stratifying the water column. Rainfall increases further during the long rains from January-May, resulting in strongstratification of the water column (Talling, 1966). During the two years sampling period (2009-2011), corresponding seasons were generally similar in the onset of rains and trends in wind speed and temperature in the Mwanza Gulf, but during the long rainy period of 2010 precipitation was twice as high as in the following rainy period in 2011 (ESM Fig. S1).

\section{Data collection}

Samples were collected during the short rains in September-November 2009, the long rains from April to May 2010 and from January to March 2011, and during the dry season from July to August 2010. All stations were sampled in each season, except for station 6, which was not sampled during the dry season. 
For stable isotopes, fish and invertebrates were collected according to Cornelissen et al. (2017). Fish $<5 \mathrm{~cm}$ standard length (SL) were skinned and filleted whole. Of fish $>5 \mathrm{~cm} \mathrm{SL}$, ca. $0.5 \mathrm{~cm}^{3}$ of skinned, dorsal muscle tissue was collected. Whole specimens of invertebrates were preserved. Gastropods were collected and kept in regularly refreshed distilled water to remove food particles from their digestive tracts. Shells were then removed and body tissue preserved. Samples were preserved in $70 \%$ ethanol and stored at $-20^{\circ} \mathrm{C}$. The processing and laboratory analyses of stable isotopes were performed according to Cornelissen et al. (2017). The isotope ratios were measured against reference standards of carbon and nitrogen by using USGS40 L-glutamic Acid C5H9NO4, with $\delta^{15} \mathrm{~N}$ of $-4.5 \%$ and $\delta^{13} \mathrm{C}$ of $-26.389 \%$ (SDs were 0.13 and 0.11 for $\delta^{13} \mathrm{C}$ and $\delta^{15} \mathrm{~N}$ values, respectively). The differences between isotopic ratio $(\mathrm{R})$ of samples and the standard were calculated as:

$\delta^{13} \mathrm{C} \%$ or $\delta^{15} \mathrm{~N} \%=\left[\left(R_{\text {sample }}-R_{\text {standard }}\right) / R_{\text {standard }}\right] \times 1000$

where $\mathrm{R}={ }^{13} \mathrm{CO}_{2}:{ }^{12} \mathrm{CO}_{2}$ or $\mathrm{R}={ }^{15} \mathrm{~N}_{2}:{ }^{14} \mathrm{~N}_{2} . \delta^{13} \mathrm{C}$ values were corrected for lipid contents (Cornelissen et al., 2017; Post et al., 2007).

Diets of Nile perch $<5 \mathrm{~cm}$ SL were analysed by dissecting the stomachs. Stomach fullness was estimated as described in Cornelissen et al. (2015). Prey were categorized as: cladoceran, calanoid copepod, cyclopoid copepod, Caridina shrimp and insect larvae. Numbers of prey in stomachs were counted. To estimate the volume percentages of the different prey in stomachs, the mean body size of prey, measured in the Mwanza Gulf during the study period, and known length-weight relationships of prey were used. Length weight relationships of Hart (1980) and Leuven et al. (2008) were used for estimating mean dry weight for Caridina shrimp. Insect larvae were of a similar size range as Caridina and therefore the same mean dry weight was used for estimating biovolumes. For zooplankton, we used the mean body size of calanoids, cyclopoids and cladocerans caught in the Mwanza Gulf during our study for calculating dry weights. We used taxa of calanoids, cyclopoids and cladocerans of similar size ranges as in the Mwanza Gulf to estimate dry weights from length-weight relationships of Bottrel et al. (1976) and Culver et al., (1985). The mean dry weights of taxa based on the aforementioned length-weight relationships were then used for estimating volume percentages of calanoids, cyclopods and cladocerans.

Diets of Nile perch $>5 \mathrm{~cm}$ SL were analysed by dissecting the stomachs following the method of Witte and van Densen (1995). Stomach fullness was estimated as described in Cornelissen et al. (2015). Prey were categorized as: gastropods, dragon fly nymph, Caridina, Rastrineobola argentea, Nile perch, haplochromines and unidentified fish remains. Diet compositions were used to calculate trophic levels of Nile perch (Adams et al., 1983; Winemiller, 1990):

$T L_{i}=1+\sum_{j=1}^{n} T L_{j}\left(f_{i j}\right)$

where $T L_{i}$ is the trophic level of Nile perch, $T L_{j}$ is the trophic level of prey taxon $j$, $f_{i j}$ is the volumetric fraction of consumed prey taxon $j$ by Nile perch $i$. We used the stable isotope profiles of the prey taxa to calculate their trophic levels. Calculations were based on a two-end-member mixing model of Post (2002), following Cornelissen et al., (2017): gastropods $=1.8$, Caridina nilotica $=2.1$, dragon fly nymph $=1.4$, juvenile Nile perch $=3$, Haplochromines $=3.3$, fish of unknown taxa $=3$.

\section{Data analysis}

We applied Bayesian mixing models to the stable isotope data (Parnell et al., 2008) to estimate the relative diet composition for 5 Nile perch size classes ( $<5 \mathrm{~cm}, 5-10 \mathrm{~cm}, 10-20 \mathrm{~cm}, 20-40 \mathrm{~cm}$ and $>40 \mathrm{~cm} \mathrm{SL}$ ) and compared the results with the relative diet contributions of stomach contents. We ran the model with prior information on stomach content proportions of prey for each size class. Only prey types with mean proportions of $>0.05$ found in stomachs were included as isotope sources in the models, to avoid over-estimation of rare food types. The stomach diet category 'unidentified fish remains' was assigned to the diet categories 'Nile perch', ' Rastrineobola argentea' and 'haplochromines' according to the proportions found in stomachs per size class. Nile perch of $<5$ $\mathrm{cm}$ were only sampled in one season and one region and therefore we ran the model with stable isotope resource variation based on that season and region. We used 500,000 iterations to run the model. We assumed a fractionation factor per trophic level of 2.4\% for $\delta^{15} \mathrm{~N}$ (Lake Tanganyika: Kilham et al., 2009) and $0.4 \%$ for $\delta^{13} \mathrm{C}$ (Post, 2002). 
For the Bayesian analyses of diet contributions and ontogenetic diet shifts of stable isotopes normality is assumed. To achieve normality, we excluded multivariate outliers for the non-normally distributed size classes. Normality could not be achieved for size class 10-20 cm SL, but parallel analyses, either including the outliers, or leaving out $5 \%$ extreme values from the 10-20 cm SL class, resulted in similar estimates, which we therefore considered reliable. For the diet contributions of stomachs, we bootstrapped the mean contributions by using 10,000 iterations for calculating 95\% confidence intervals.

The effects of region, season, SL, and their interactions on $\delta^{15} \mathrm{~N}$ and $\delta^{13} \mathrm{C}$ stable isotope ratios, and on dietderived trophic levels of Nile perch $>5 \mathrm{~cm}$ were analysed by analysis of variance (ANOVA). The effect of SL on $\delta^{15} \mathrm{~N}$ and on diet-derived trophic levels were separately analysed for each region-season combination with linear regressions. For diet-derived trophic levels, we used $0.1 \mathrm{~cm}$ size classes of Nile perch and weighted the diet proportions on the number of observations per size class. We used size class as a continuous length effect for the ANOVA and linear regressions. Before analyses the lowest and highest 5\% observations were trimmed from the distributions to decrease the influence of extreme values on estimates.

Binomial logistic regressions were used to relate SL of Nile perch with the occurrence of Caridina or haplochromines in the diet of stomach contents. The length (SL) at a probability of occurrence of 0.5 is considered the length at which Nile perch ontogenetically shifts its diet, in this case towards haplochromines or away from feeding on Caridina. For the long rains in 2010, the length at a probability of 0.5 could not be estimated properly and was excluded from the results.

All statistics were performed in R version 3.1.0 (R Core Team, 2014). Isotopic diet contributions were calculated using the SIAR package (Parnell et al 2008). Multivariate outliers were detected by using the mvoutlier package. For bootstrapping the mean contributions of stomach contents, the Mosaic package was used.

\section{Results}

Ontogenetic diet shift of Nile perch

Nile perch examined were predominantly juveniles, but covered a length range that could be expected to include the most important ontogenetic diet shifts $(1.5-65 \mathrm{~cm})$ (Table 1 and 2). Stable isotope ratios of 516 Nile perch were analysed (Table 1$)$. The smallest length class of Nile perch $(<5 \mathrm{~cm} \mathrm{SL})$ showed the most distinct isotopic signature with a low mean $\delta^{15} \mathrm{~N}$ value of 6.1 and an enriched mean $\delta^{13} \mathrm{C}$ value of $-13.1 \%$ (Fig. 2). Nile perch size classes of 5-10, 10-20, 20-40 and $>40 \mathrm{~cm}$ SL showed much higher $\delta^{15} \mathrm{~N}$ values, increasing with size from 8.0 to 9.3 , all with similar mean $\delta^{13} \mathrm{C}$ values of -16.9 to $-17.1 \%$ o (Fig. 2). A total of 98 invertebrate prey items were analysed for stable isotope ratios, including gastropods, zooplankton, Caridina shrimp and dragonfly nymphs (Table 1). Mean $\delta^{15} \mathrm{~N}$ values of invertebrate prey ranged from 4.9-6.7\%o (Fig. 2). Invertebrates showed a large variation in $\delta^{13} \mathrm{C}$ values, ranging from -15.1 to $-19.1 \%$. A total of 197 haplochromine cichlid prey were sampled for stable isotope ratios, including three trophic groups which were previously identified by Witte and van Oijen (1990) as zooplanktivores, detritivores and piscivores (Table 1). We mainly observed zooplanktivores and detritivores (>94\%); identification to species level was not possible. Mean $\delta^{15} \mathrm{~N}$ values of haplochromine groups were similar and ranged between 8.2 and $8.7 \%$ (Fig. 2). In contrast the mean $\delta^{13} \mathrm{C}$ values showed much variation and ranged from -14.4 to $-17.3 \%$, with piscivore haplochromines relatively enriched in $\delta^{13} \mathrm{C}$ compared to the other groups (Fig. 2). A total of 20 samples were analysed for stable isotope ratios of dagaa (Table 1). Dagaa showed a high mean $\delta^{15} \mathrm{~N}$ value of $9.3 \%$ and an enriched mean $\delta^{13} \mathrm{C}$ value of $-14.9 \%$ (Fig. 2). 
Table 1 Number of observations of stable isotopes values of Nile perch and prey organisms at the three regions (R1-R3) in the Mwanza Gulf. A total of 516 Nile perch and 290 prey organisms were sampled. Total numbers are in bold.

\begin{tabular}{|c|c|c|c|c|c|c|c|c|c|c|c|c|c|}
\hline & \multicolumn{3}{|c|}{ Short rains 2009} & \multicolumn{3}{|c|}{ Long rains 2010} & \multicolumn{3}{|c|}{ Dry season 2010} & \multicolumn{3}{|c|}{ Long rains 2011} & \multirow[t]{2}{*}{ Total } \\
\hline & R1 & $\mathrm{R} 2$ & R3 & R1 & R2 & R3 & R1 & R2 & R3 & R1 & R2 & R3 & \\
\hline Lates niloticus & 73 & 61 & 43 & 9 & 18 & 12 & 77 & 92 & 31 & 42 & 32 & 26 & 516 \\
\hline$<5 \mathrm{~cm}$ & & & & & & & & & & 7 & & & 7 \\
\hline $5-10 \mathrm{~cm}$ & 11 & 22 & 11 & 4 & 2 & 1 & 14 & 20 & 5 & 9 & 9 & 11 & 119 \\
\hline $10-20 \mathrm{~cm}$ & 19 & 15 & 8 & 1 & 3 & 1 & 23 & 28 & 7 & 8 & 7 & 5 & 125 \\
\hline $20-40 \mathrm{~cm}$ & 30 & 21 & 17 & 4 & 6 & 8 & 38 & 37 & 14 & 18 & 16 & 10 & 219 \\
\hline$>40 \mathrm{~cm}$ & 13 & 3 & 7 & & 7 & 2 & 2 & 7 & 5 & & & & 46 \\
\hline Gastropods & 1 & 5 & 5 & 2 & 2 & 1 & 4 & 2 & 1 & 7 & 5 & 7 & 42 \\
\hline Microcrustacean zooplankton & 3 & 2 & 3 & 1 & & 1 & 1 & 1 & 1 & 2 & 1 & 1 & 17 \\
\hline Caridina nilotica & & & 2 & 2 & 2 & 1 & 6 & 6 & 5 & 2 & 2 & 4 & 32 \\
\hline Anisoptera nymph & & & & & & 1 & 3 & 3 & & & & & 7 \\
\hline Haplochromine 'detritivore' cichlid & & & 3 & & & & 12 & 13 & 2 & 12 & 23 & 28 & 93 \\
\hline Haplochromine 'zooplanktivore' cichlid & 17 & 17 & 26 & & & & 5 & 3 & 2 & & & & 70 \\
\hline Haplochromine ‘unidentified' cichlid & 8 & 11 & 5 & 4 & 2 & 4 & & & & & & & 34 \\
\hline Haplochromine 'piscivore' cichlid & & & & & & & & & & & & & 6 \\
\hline Rastrineobola argentea & & & & & & & & & & 5 & 10 & 5 & 20 \\
\hline
\end{tabular}

Table 2 Number of stomachs analysed for diet composition of Nile perch in the Mwanza Gulf. A total of 6697 stomachs were analysed.

\begin{tabular}{|c|c|c|c|c|c|c|c|c|c|c|c|c|c|}
\hline & \multicolumn{3}{|c|}{ Short rains 2009} & \multicolumn{3}{|c|}{ Long rains 2010} & \multicolumn{3}{|c|}{ Dry season 2010} & \multicolumn{3}{|c|}{ Long rains 2011} & \multirow[t]{2}{*}{ Total } \\
\hline & R1 & $\mathrm{R} 2$ & R3 & R1 & R2 & R3 & R1 & $\mathrm{R} 2$ & R3 & R1 & R2 & R3 & \\
\hline \multicolumn{14}{|l|}{ Lates niloticus } \\
\hline$<5 \mathrm{~cm}$ & & & & & & & 91 & 49 & 15 & & & & 155 \\
\hline $10-20 \mathrm{~cm}$ & 346 & 285 & 1159 & 122 & 71 & 116 & 95 & 108 & 13 & 240 & 405 & 458 & 3418 \\
\hline $20-40 \mathrm{~cm}$ & 113 & 94 & 144 & 27 & 37 & 34 & 78 & 88 & 20 & 89 & 85 & 71 & 880 \\
\hline Full stomachs (\%) & 67.6 & 65.1 & 60.5 & 51.8 & 55.0 & 46.1 & 61.3 & 57.0 & 52.8 & 56.9 & 57.1 & 49.4 & 58 \\
\hline
\end{tabular}

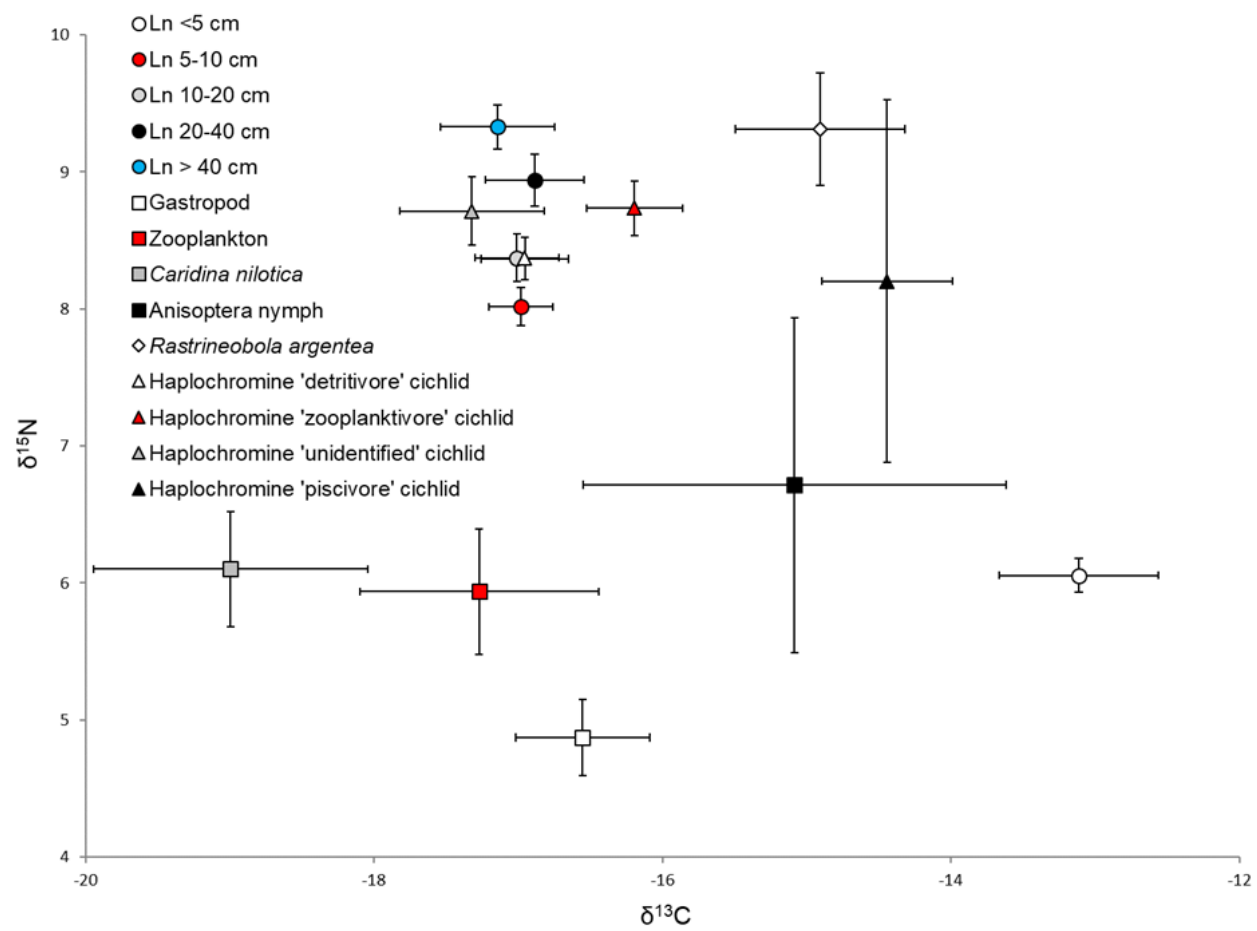

Fig. 2 Mean $\delta^{13} \mathrm{C}$ and $\delta^{15} \mathrm{~N}$ isotope values with standard errors of Nile perch and prey taxa in the Mwanza Gulf. 


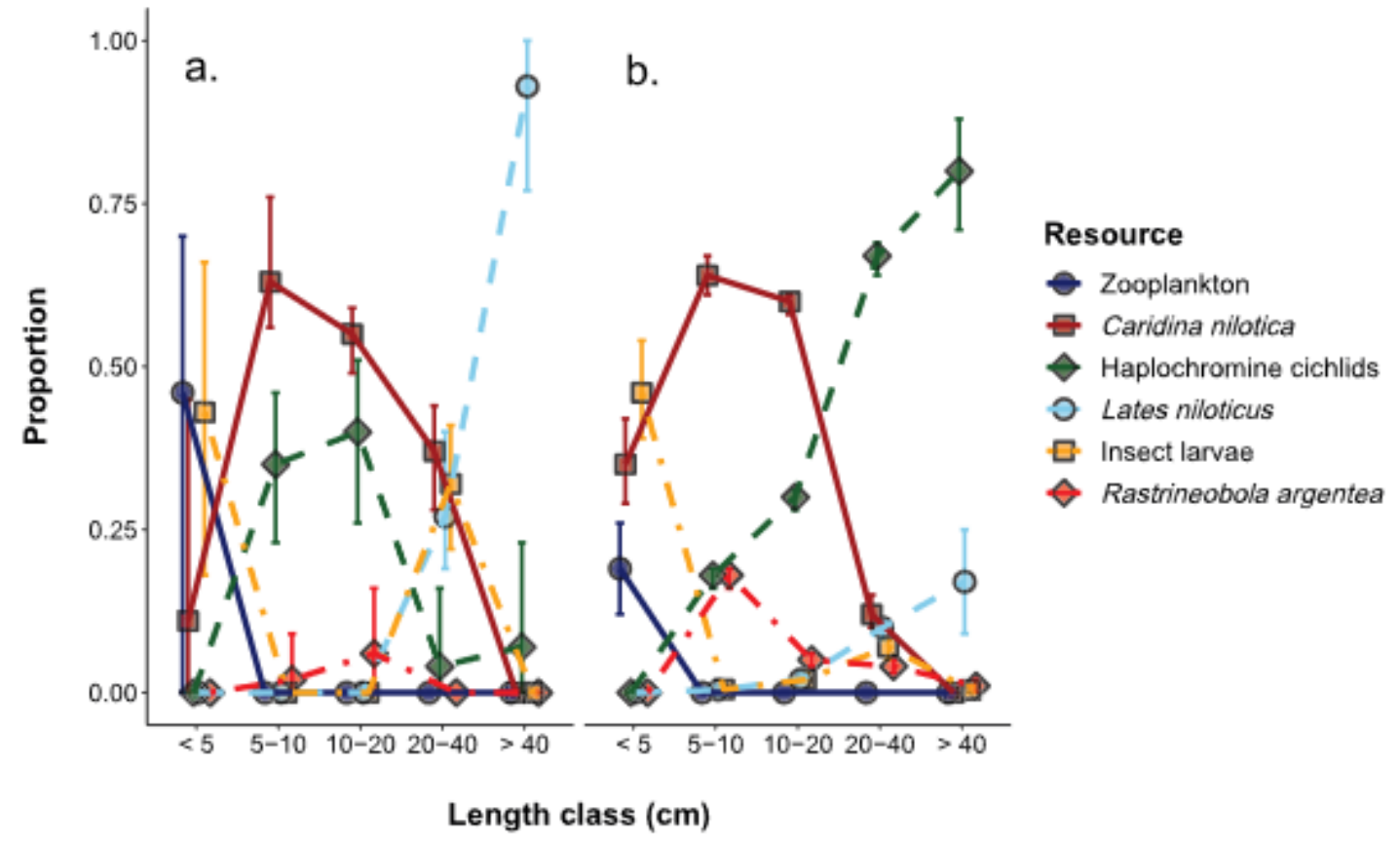

Fig. 3 Mean relative diet contributions of Nile perch size classes a) based on stable isotopes and b) based on stomach contents. Gastropods were excluded from the graph because of low contributions. Diet contributions based on stable isotopes with 95\% probability intervals and diet contributions based on stomach contents with 95\% confidence intervals.

Based on the results of the isotope mixing model zooplankton and insect larvae contributed most to the diet of Nile perch of $<5 \mathrm{~cm}$ (proportion of 0.46 and 0.43), whereas Caridina shrimp contributed less (0.11) (Fig. 3a, ESM Table S1). Caridina shrimp and haplochromines contributed most to the diet of Nile perch 5-10 cm and 10$20 \mathrm{~cm}$ (0.35-0.63), while shrimps, insect larvae and juvenile Nile perch contributed most to the diet of Nile perch $20-40 \mathrm{~cm}(0.27-0.37)$. Finally, juvenile Nile perch dominated the diet of Nile perch $>40 \mathrm{~cm}$ (0.93). Dagaa contributed little to the diet in all size classes $(<0.06)$.

A total of 6697 stomachs of Nile perch were analysed for diet composition (Table 2). Prey remains were found in $58 \%$ of the stomachs. The diet composition (biovolume proportions) varied for the different size classes of Nile perch (Fig. 3b, ESM Table S1). Caridina shrimp and insect larvae were the most common prey items in Nile perch $<5 \mathrm{~cm}$ SL (proportions of 0.35 and 0.46 ), while zooplankton contributed less (0.19). Caridina shrimp were the most dominant prey in Nile perch size classes of 5-10 cm and 10-20 cm (0.64 and 0.60). Haplochromines were the most dominant prey in Nile perch size classes of $20-40 \mathrm{~cm}$ and $>40 \mathrm{~cm}(0.67$ and 0.80$)$. Of the fish prey, haplochromine cichlids showed the highest contribution to Nile perch diet $(0.18-0.8)$, whereas juvenile Nile perch and dagaa contributed less to the diet $(<0.18)$.

The $\delta^{15} \mathrm{~N}$ values increased significantly with length of Nile perch in the Mwanza Gulf, with a slope of $0.042 \% \mathrm{~cm}^{-1}$, indicating an ontogenetic diet shift (Fig. 4a); while the $\delta^{13} \mathrm{C}$ values did not relate to Nile perch length (Fig. 4b). Stomach content analysis showed that the diet contribution of haplochromines increased with Nile perch SL, whereas the diet contribution of Caridina shrimp decreased (Fig. 5). Overall, the ontogenetic diet shift of Nile perch from Caridina to feeding on haplochromines occurred at a SL of $16.7 \mathrm{~cm}$ (Fig. 5). 

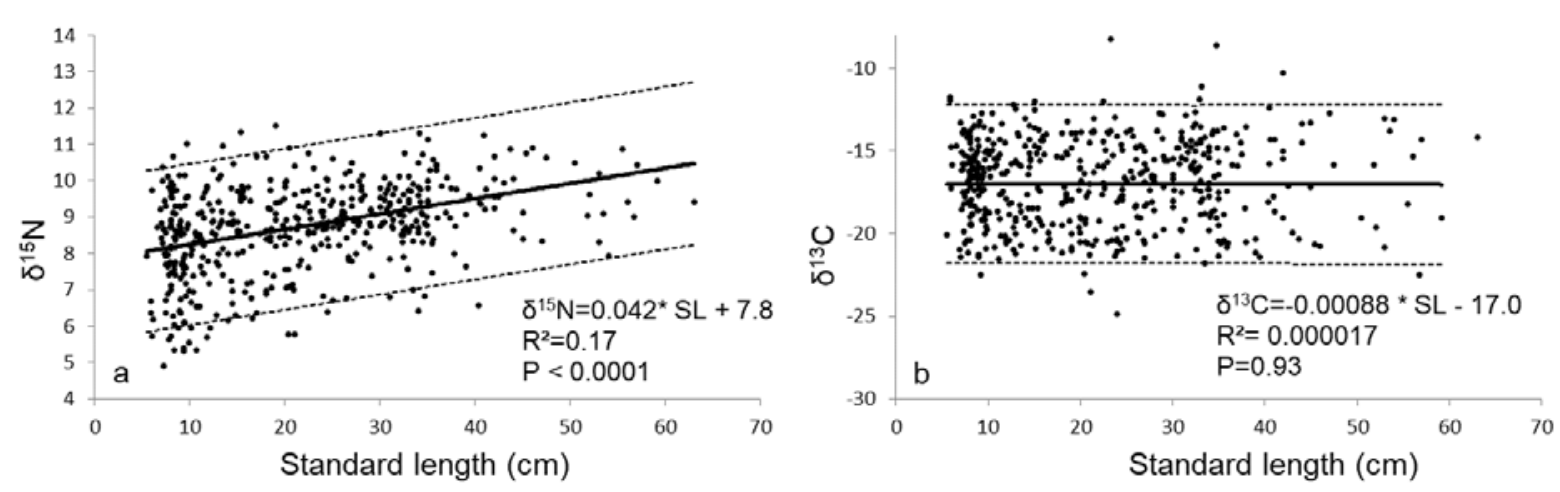

Fig. 4 Linear regression between standard length of Nile perch and a) $\delta 15 \mathrm{~N}$ isotope values and b) $\delta 13 \mathrm{C}$ isotope values of Nile perch in the Mwanza Gulf.

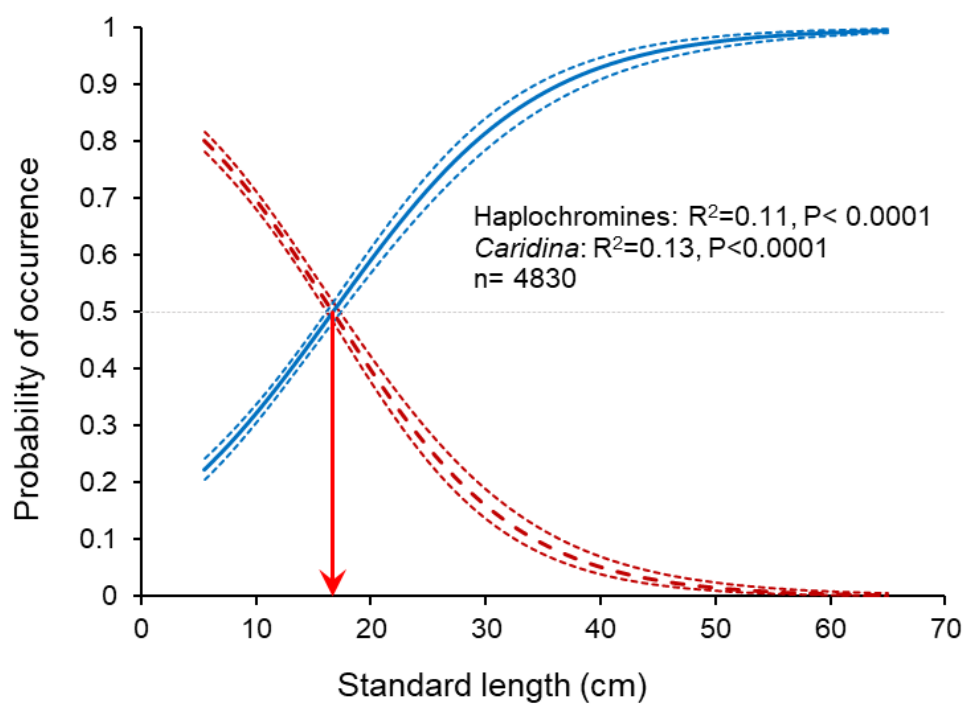

Fig. 5 Relationship between standard length and probability of occurrence of haplochromines (solid line) or Caridina shrimp (broken line) in the diet of Nile perch in the Mwanza Gulf. Ontogenetic diet shift towards haplochromines occurred at a Nile perch length of $16.7 \mathrm{~cm}$ (95\% confidence interval (CI): 16.2-17.4 cm) and away from Caridina at $16.7 \mathrm{~cm}(95 \% \mathrm{CI}: 16.1-17.2 \mathrm{~cm})$.

Spatial and seasonal variation in diet shifts of Nile perch

Seasons and the interaction between regions and seasons had an effect on $\delta^{13} \mathrm{C}$ values, but $\delta^{13} \mathrm{C}$ values were not related to region, length, or any of the other two-or three-way interactions (Table 3). Also for $\delta^{15} \mathrm{~N}$ values, seasons and the interactions between regions and seasons, and between Nile perch lengths and seasons had a significant effect. Season, length, the interaction between region and season and the three-way interaction between length, region and season had significant effects on the trophic level based on stomach contents (Table 3). 
Table 3 Effect of region, season and standard length on $\delta^{13} \mathrm{C}$ and $\delta^{15} \mathrm{~N}$ isotope values, and on trophic levels based on stomach contents of Nile perch.

\begin{tabular}{|c|c|c|c|c|c|c|c|c|c|}
\hline & \multicolumn{6}{|c|}{ Isotopes } & \multicolumn{3}{|c|}{ Stomach content } \\
\hline & \multicolumn{3}{|c|}{$\delta^{13} \mathrm{C}$} & \multicolumn{3}{|c|}{$\delta^{15} \mathrm{~N}$} & \multicolumn{3}{|c|}{ Trophic level } \\
\hline & $\mathrm{df}$ & $\mathrm{F}$ & $\mathrm{P}$ & $\mathrm{df}$ & $\mathrm{F}$ & $\mathrm{P}$ & $\mathrm{df}$ & $\mathrm{F}$ & $\mathrm{P}$ \\
\hline Region & 2 & 2.63 & N.S. & 2 & 0.43 & N.S. & 2 & 0.10 & N.S. \\
\hline Season & 3 & 5.65 & $<0.001$ & 3 & 18.77 & $<0.0001$ & 3 & 8.39 & $<0.0001$ \\
\hline Region $\times$ season & 6 & 4.07 & $<0.001$ & 6 & 3.24 & $<0.01$ & 6 & 8.16 & $<0.0001$ \\
\hline SL & 1 & 0.13 & N.S. & 1 & 0.32 & N.S. & 1 & 9.95 & $<0.001$ \\
\hline $\mathrm{SL} \times$ region & 2 & 1.02 & N.S. & 2 & 0.17 & N.S. & 2 & 0.42 & N.S. \\
\hline SL $\times$ season & 3 & 1.38 & N.S. & 3 & 5.67 & $<0.001$ & 3 & 0.76 & N.S. \\
\hline $\mathrm{SL} \times$ region $\times$ season & 6 & 1.80 & N.S. & 6 & 1.65 & N.S. & 6 & 3.93 & $<0.001$ \\
\hline Residuals & 437 & & & 437 & & & & & \\
\hline
\end{tabular}

Linear regressions of $\delta^{15} \mathrm{~N}$ values, and stomach-based trophic levels against SL for each region-season combination were used to investigate spatial and seasonal variation in trophic levels with size. The $\delta^{15} \mathrm{~N}$-values were increasing with Nile perch length in region 1 and 2 during the short rains of 2009 and the long rains in 2010 and 2011, while there was no relationship with length in the dry season in any of the regions (Table 4). Stomach-based trophic levels increased with length in all regions during the short rains of 2009, dry season of 2010 and long rains of 2011, while during the long rains of 2010 this was only the case in region 2 (Table 4).

Table 4 Linear regressions of $\delta^{15} \mathrm{~N}$ isotope values and trophic levels based on stomach contents on standard length of Nile perch. Regressions were performed separately for each region-season combination.

\begin{tabular}{|c|c|c|c|c|c|c|c|c|c|}
\hline \multirow{5}{*}{$\delta^{15} \mathrm{~N}$} & & \multicolumn{4}{|c|}{ Short rains 2009} & \multicolumn{4}{|c|}{ Long rains 2010} \\
\hline & & Intercept & Slope & $\mathrm{P}$ & d.f. res. & Intercept & Slope & $\mathrm{P}$ & d.f. res. \\
\hline & Region 1 & 8.54 & 0.019 & $<0.001$ & 64 & 7.07 & 0.069 & $<0.001$ & 5 \\
\hline & Region 2 & 7.06 & 0.064 & $<0.0001$ & 52 & 7.38 & 0.053 & $<0.01$ & 14 \\
\hline & Region 3 & 8.80 & - & N.S. & 36 & 8.24 & - & N.S. & 8 \\
\hline \multirow{3}{*}{$\begin{array}{l}\text { Stomach content } \\
\text { trophic level }\end{array}$} & Region 1 & 3.49 & 0.008 & $<0.001$ & 151 & 3.47 & - & N.S. & 64 \\
\hline & Region 2 & 3.00 & 0.028 & $<0.0001$ & 139 & 3.85 & 0.005 & $<0.05$ & 52 \\
\hline & Region 3 & 2.90 & 0.028 & $<0.0001$ & 196 & 3.94 & - & N.S. & 62 \\
\hline \multirow{5}{*}{$\delta^{15} \mathrm{~N}$} & \multirow[b]{3}{*}{ Region 1} & \multicolumn{4}{|c|}{ Dry season 2010} & \multicolumn{4}{|c|}{ Long rains 2011} \\
\hline & & Intercept & Slope & $\mathrm{P}$ & d.f. res. & Intercept & Slope & \multirow{2}{*}{$\begin{array}{l}\mathrm{P} \\
<.0001\end{array}$} & d.f. res \\
\hline & & 8.69 & - & N.S. & 68 & 6.18 & 0.073 & & 35 \\
\hline & Region 2 & 9.00 & - & N.S. & 81 & 6.33 & 0.050 & $<0.05$ & 27 \\
\hline & Region 3 & 8.79 & - & N.S. & 26 & 6.63 & - & N.S. & 21 \\
\hline \multirow{3}{*}{$\begin{array}{l}\text { Stomach content } \\
\text { trophic level }\end{array}$} & Region 1 & 3.12 & 0.016 & $<0.05$ & 77 & 3.72 & 0.007 & $<0.05$ & 134 \\
\hline & Region 2 & 3.18 & 0.011 & $<0.05$ & 98 & 3.41 & 0.010 & $<0.01$ & 159 \\
\hline & Region 3 & 3.17 & 0.017 & $<0.05$ & 20 & 3.18 & 0.018 & $<0.0001$ & 146 \\
\hline
\end{tabular}

Ontogenetic diet shifts, expressed as the length at which Nile perch switched towards feeding on haplochromines or away from feeding on Caridina were found in all region-season combinations except during the long rains of 2010, where shift lengths could not be reliably estimated from logistic regressions. In the dry season, lengths of diet shifts did not vary between regions, while in the short rains, Nile perch shifted at smaller lengths in region 1 than in region 2 and 3 (Fig. 6a, b). In the long rains of 2011 the pattern was similar: in region 1 the diet shift apparently occurred at smaller Nile perch length than we sampled $(<6.7 \mathrm{~cm})$. Nile perch shifted to haplochromines at a similar length as when it shifted away from Caridina (Fig. 7). 

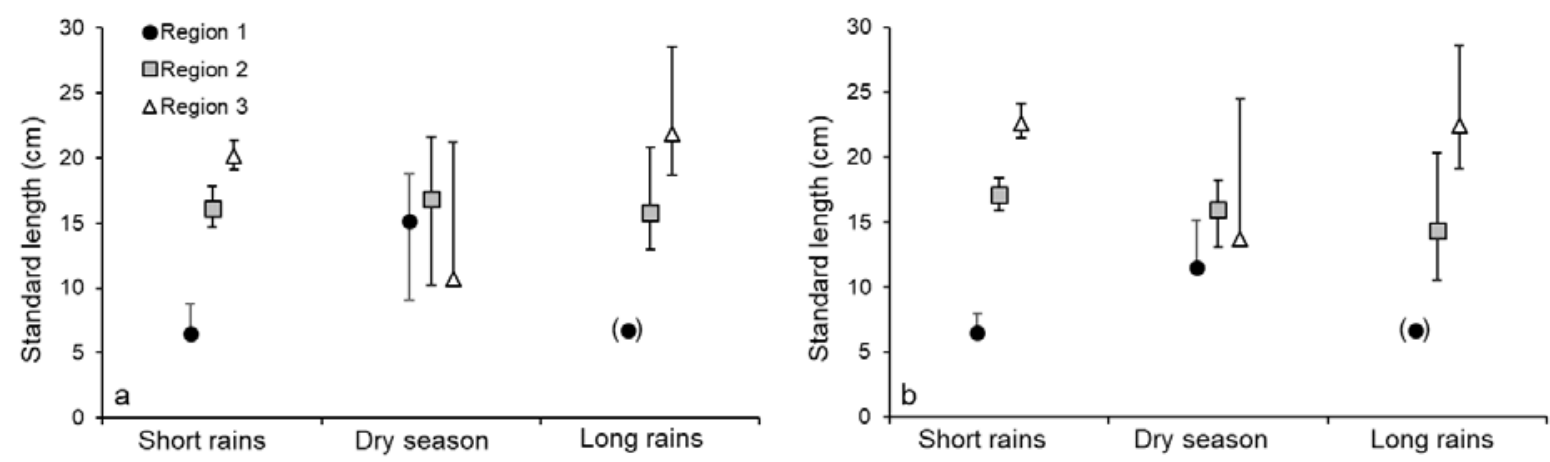

Fig. 6 Spatial and seasonal variation in the length at which Nile perch ontogenetically shift its diet a) towards haplochromines and b) away from Caridina shrimp. Error bars represent 95\% confidence intervals. Ontogenetic length in region 1 in long rains of 2011 was smaller than the length of Nile perch we recorded for stomach content analyses $(<6.7 \mathrm{~cm})$ and is therefore displayed within brackets. Ontogenetic lengths in long rains 2010 could not be estimated and excluded from the figure. Missing error bars indicates that confidence intervallengths were not within the range of lengths measured for Nile perch in the Mwanza Gulf.

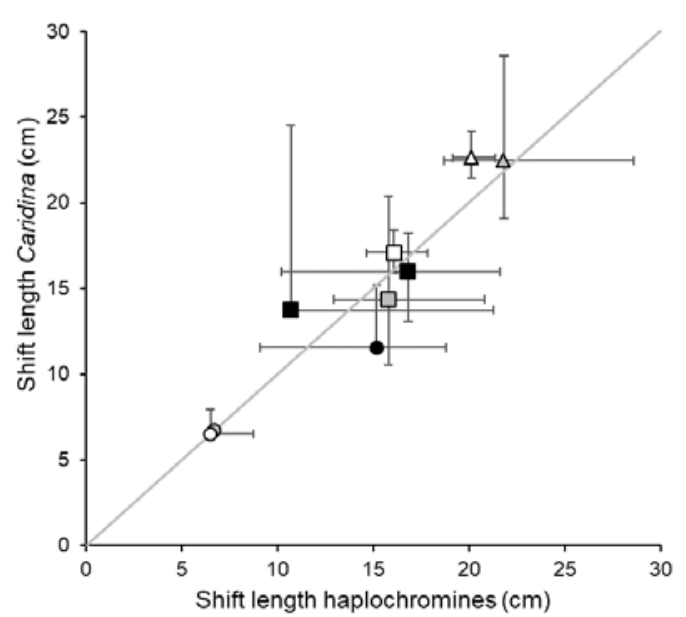

Fig. 7 Ontogenetic diet shifts of Nile perch with length shifts towards haplochromines related to length shifts away from Caridina. The diagonal line represents that length shifts from Caridina to haplochromines occurs simultaneously. Length shifts above the diagonal line represent Nile perch still including Caridina in its diet while already shifted to haplochromines. Length shifts under the diagonal line represent that Nile perch shift away from Caridina occurs earlier than the shift towards haplochromines. Error bars represent $95 \%$ confidence intervals. Missing error bars indicates that confidence interval-lengths were not within the range of lengths measured for Nile perch in the Mwanza Gulf. Regions are indicated by shapes: Region 1 = circle, region 2 = square and region 3 = triangle. Seasons are indicated by shades: short rains 2009 = open, dry season $2010=$ filled black and long rains 2011 = filled grey.

\section{Discussion}

We used stable isotopes and stomach contents of Nile perch to study variations in ontogenetic diet shifts in the Mwanza Gulf in southern Lake Victoria. Nile perch examined in this study were predominantly juveniles (1.5-65 $\mathrm{cm}$ ) within the size range of ontogenetically shifting from invertebrates to fish.

Stable isotope values of $\delta^{15} \mathrm{~N}$ of Nile perch were in the same range as in Napoleon Gulf in northern Lake Victoria, but lower than in Winam Gulf and Lake Albert (Campbell et al., 2003, Campbell et al., 2005). Mean lengths of Nile perch were larger in Winam Gulf (TL of $47.9 \mathrm{~cm}$ ) and Lake Albert (TL of $43.7 \mathrm{~cm}$ ) than on the Mwanza Gulf (SL of $21.8 \mathrm{~cm}$ ) and Napoleon Gulf (TL of $35.9 \mathrm{~cm}$ ) and this may explain the higher trophic levels in the former two gulfs. $\delta^{13} \mathrm{C}$ values in Mwanza Gulf were more enriched than in Napoleon Gulf, Winam Gulf and Lake Albert. This suggests that the food chain of Nile perch in Mwanza Gulf and the northern gulfs and Lake Albert is fuelled by differences in benthic-littoral resources and affected by differences in primary production and/or nutrient recycling rates, probably caused by morphometric differences between water bodies (Campbell et al., 2003).

Stable isotopes and stomach contents of Nile perch $<5 \mathrm{~cm}$ SL indicate mainly feeding on insects, Caridina and zooplankton. This is in contrast with the zooplankton-based diet of Nile perch $<5 \mathrm{~cm}$ found in the 1980s in Mwanza Gulf (Katunzi et al., 2006), indicating that Nile perch $<5 \mathrm{~cm}$ have switched to larger prey. Caridina shrimp showed a larger contribution in stomach content than based on stable isotopes. The $\delta^{13} \mathrm{C}$ values of Caridina did not agree with the $\delta^{13} \mathrm{C}$ of Nile perch $<5 \mathrm{~cm}$, making Caridina a less likely resource in the isotope mixing model.

Based on stable isotopes of Nile perch $>5 \mathrm{~cm}$, the main diet items varied between size classes, with Caridina and haplochromines dominating the diet of Nile perch 5-10 and 10-20 cm. In Nile perch of 20-40 cm Caridina, 
Lates niloticus and insect larvae dominated the diet, whereas in Nile perch $>40 \mathrm{~cm}$ diets were strongly cannibalistic, including a large proportion of Lates niloticus. For Nile perch $<20 \mathrm{~cm}$ the diet compositions based on isotopes were similar to diets derived from stomach contents, but in Nile perch $>20 \mathrm{~cm}$ the isotope mixing model assigned more prey sources of low trophic levels, such as insect larvae, Caridina and small Nile perch, instead of prey sources of higher trophic levels, such as haplochromines, which had similar trophic levels as their Nile perch predator. This was in contrast to stomach contents where haplochromines were the main diet item, corroborating with a recent stomach content study on Nile perch diet in Mwanza Gulf (Kishe-Machumu et al., 2012).

There might be several reasons for this discrepancy between stable isotopes and stomach contents. It can be explained by the difference in timespan-coverage between isotopes and stomach contents (hours in the case of stomach contents and months in the case of stable isotopes), by diel feeding behaviour of Nile perch and by immigration of Nile perch from other parts of the lake into the Gulf (Cornelissen et al., 2017). Furthermore, variation in assimilation of $\mathrm{N}$ between types of prey, resulting in diet-source specific enrichments between trophic transfers (McCutchan et al., 2003), and the large isotopic variation within prey sources (Cornelissen et al., 2017) may also explain differences between estimated diets based on stable isotopes and stomach contents. This highlights the limits of both stable isotopes and stomach contents to estimate trophic interactions between predator and prey and the importance of using stomach contents to verify and select diets in stable isotope mixing models.

According to our own observations based on stomach contents, cannibalism and the occurrence of dagaa in Nile perch diet was low, which agrees with a recent stomach content study in Mwanza Gulf (Kishe-Machumu et al., 2012). In contrast, based on our stable isotopes, cannibalism was relatively high in Nile perch of 20-40 cm and $>40 \mathrm{~cm}$. In the 1980s in the Mwanza Gulf during the Nile perch boom, cannibalism was high and dagaa a common diet item in Nile perch stomachs (Katunzi et al., 2006), which is explained by food scarcity in absence of haplochromine prey and the switch of Nile perch to less preferred prey (Mkumbo and Ligtvoet, 1992). This suggests that according to stomach contents, with the current abundant Caridina, dagaa, juvenile Nile perch and haplochromines in the Mwanza Gulf, Nile perch prefers Caridina and haplochromines above dagaa and juvenile Nile perch. According to stable isotopes, Nile perch prefers juvenile Nile perch above haplochromines. As haplochromines were abundant in the Gulf, it is likely that the relative high cannibalism inferred from stable isotopes is overestimated. Haplochromines may be preferred above dagaa as fish prey because they are larger in size and the shoaling dagaa might be more difficult to catch.

$\delta^{15} \mathrm{~N}$ values increased with Nile perch length, suggesting an ontogenetic diet shift. This was corroborated by stomach content analyses, which showed an ontogenetic diet shift from a Caridina diet towards a haplochromines diet with increasing Nile perch length. $\delta^{15} \mathrm{~N}$ values increased less steeply with Nile perch length than observed in northern Lake Victoria, but more steeply than in Lake Albert (Slopes: Our study $=0.04$, Napoleon Gulf $=0.06$, Winam Gulf $=0.05$, Lake Albert $=0.02$ ) (Campbell et al., 2005). The differences in rates of change in $\delta^{15} \mathrm{~N}$ between water bodies indicate that ontogenetic diet shifts of Nile perch are variable. Moreover, even within Mwanza Gulf the large variations of $\delta^{15} \mathrm{~N}$ at any given size indicate variability in ontogenetic diet shift of Nile perch. $\delta^{13} \mathrm{C}$ values did not change with Nile perch length in our study, suggesting that Nile perch does not shift to a food web with a different basal carbon source when increasing in size. This is in contrast to the northern Gulfs of Lake Victoria, where $\delta^{13} \mathrm{C}$ values significantly increased with length, explained by the increase of littoral-based tilapia in their diet with size (Campbell et al., 2003, 2005).

The importance of Caridina shrimp in stomach contents decreased with Nile perch length based on both stomach contents and stable isotopes. The importance of haplochromines in the diet increased with length only based on stomach contents. This agrees with previous observations of stomach contents (Budeba and Cowx, 2007; KisheMachumu et al., 2012). The ontogenetic diet shift towards haplochromines based on stomach contents occurred at a similar length as observed in 2006 and 2008 in the Mwanza Gulf (Kishe-Machumu et al., 2012). Haplochromines dominated the diet of Nile perch from $21 \mathrm{~cm}$ total length (TL) onwards (Table 1, Kishe-Machumu et al., 2012). In our study, the overall diet shift towards haplochromines occurred at a slightly smaller length of $16.7 \mathrm{~cm}$ SL (19.6 $\mathrm{cm} \mathrm{TL}$ ). Moreover, the shift towards haplochromines occurred in specimens as small as $6.5 \mathrm{~cm}$ in some parts of the Gulf, indicating the large flexibility in the feeding behaviour of Nile perch.

Both the isotope- and stomach contents-based estimates showed a clear spatial and seasonal differentiation in ontogenetic diet shifts in Mwanza Gulf. In the dry season, $\delta^{15} \mathrm{~N}$ values did not increase with Nile perch length. This agrees with the shift lengths based on stomach contents, which showed large variations and did not show a significant spatial differentiation in the length at which diet shifts towards haplochromines occurred. In the short and long rainy seasons, $\delta^{15} \mathrm{~N}$ values and trophic levels based on stomach content significantly increased with length 
in most regions and there was a clear spatial differentiation in the lengths at which diet shifts occurred. These seasonal and spatial trends are in line with what was found on a food-web level in the Mwanza Gulf based on stable isotopes, where resource use of fish was strongly influenced by increased run-off during the rains, resulting in spatial differentiation in resources at the base of the food web and by winds during the dry season, resulting in a mixed resource use. Furthermore, on a food-web level in tropical estuaries, the trophic structure was strongly influenced by the rainy seasons based on stable isotopes (Abrantes et al., 2014).

The late diet shift to haplochromines of Nile perch at the entrance of the Mwanza Gulf during rainy seasons might be explained by a seasonal variation in availability of Caridina. High densities of Caridina and their large diet contribution in Nile perch in deep waters and during rainy periods were found in other studies (Cornelissen et al., 2015; Goudswaard et al., 2006; Katunzi et al., 2006) and suggest a distinct pattern in the availability of Caridina. It is suggested that Caridina migrates seasonally from shallow waters to deep waters to breed (Budeba and Cowx, 2007) and that during periods of stratification, Caridina might find refuge below the thermocline where oxygen levels are too low for Nile perch to forage (Mkumbo, 2002). During our study in Mwanza Gulf, stratification was weak and the water column was fully oxygenated (Cornelissen et al., 2014, 2015). However, if further eutrophication of Lake Victoria continues and persistent anoxic layers develop, Caridina might be more difficult to forage on by Nile perch in deep waters and Nile perch might shift back to feeding on dagaa and their own juveniles in those regions where haplochromines are scarce. The large contribution of haplochromines in Nile perch diet in the south of the Mwanza Gulf confirms the recovery of haplochromines in littoral waters of the Mwanza Gulf (Kishe-Machumu et al., 2015; Witte et al., 2007). The scale of the recovery and thus the availability for Nile perch in other regions in Lake Victoria is largely unknown (Kishe-Machumu et al., 2015). A further recovery of haplochromines in Lake Victoria may lead to Nile perch increasingly relying on haplochromines as before the decline of haplochromines in the 1980s.

\section{Acknowledgments}

This work is part of the integrated project "Exploitation or eutrophication as threats for fisheries? Disentangling social and ecological drivers of ecosystem changes in Lake Victoria (SEDEC)”. This work was supported by the Netherlands Organisation for Scientific Research (NWO/WOTRO) grant number W01.65.304.00. Special thanks to dr. Frans Witte for his scientific advice, Klaas Gerber, Alex Mangassa, Gerardi Rajabu, Paulo and Emma for their valuable field assistance and support, and to the Tanzanian Fisheries Research Institute (TAFIRI) in Mwanza for providing laboratory space and use of field equipment during this research. This is publication No. 6592 of the Netherlands Institute of Ecology (NIOO-KNAW). 


\section{References}

Abrantes, K.G., Barnett, A., Bouillon, S.l, 2014. Stable isotope-based community metrics as a tool to identify patterns in food web structure in east African estuaries. Funct. Ecol. 28, 270-282.

Adams, S.M., Kimmel, B.L., Plosky, R.l, 1983. Sources of organic matter for reservoir fish production: a trophic dynamics analysis. Can. J. Fish. Aquat. Sci. 40, 1480-1495.

Akiyama, T., Kajumulo, A.A., Olsen, S.l, 1977. Seasonal variation of plankton and physicochemical condition in Mwanza Gulf, Lake Victoria. Bull. Freshw. Fish. Res. Lab. 27, 48-61.

Bottrell, H.H., Duncan, A., Gliwicz, Z.M., Grygierek, E., Herzig, A., Hillbricht-Ilkowska, A., Kurasawa, H., Larsson, P., Weglenska, T.l, 1976. A review of some problems in zooplankton production studies. Nor. J. Zool. 24, 419-456.

Budeba, Y.L., Cowx, I.G.l, 2007. The role of the freshwater shrimp Caridina nilotica (Roux) in the diet of the major commercial fish species in Lake Victoria, Tanzania. Aquat. Ecosyst. Health Manage. 10, 368-380.

Campbell, L.M., Hecky, R.E., Wandera, S.B.l, 2003. Stable isotope analyses of food web structure and fish diet in Napoleon and Winam Gulfs, Lake Victoria, East Africa. J. Great Lakes Res. 29, 243-257.

Campbell, L.M., Wandera, S.B., Thacker, R.J., Dixon, D.G., Hecky, R.E.l, 2005. Trophic niche segregation in the Nilotic ichthyofauna of Lake Albert (Uganda, Africa). Environ. Biol. Fish 74, 247-260.

Cocheret de la Morinière, E., Pollux, B.J.A., Nagelkerken, I., Hemminga, M.A., Huiskes, A.H.L., van der Velde, G.l, 2003. Ontogenetic dietary changes of coral reef fishes in the mangrove-seagrass-reef continuum: stable isotopes and gut-content analysis. Mar. Ecol. Prog. Ser. 246, 279-289.

Cornelissen, I.J.M., Silsbe, G., Verreth, J.A.J., van Donk E., Nagelkerke, L.A.J., 2014. Dynamics and limitations of phytoplankton biomass along a gradient in Mwanza Gulf, southern Lake Victoria (Tanzania). Freshw. Biol. 59, 127-141.

Cornelissen, I.J.M., van Zwieten, P.A.M., Peter, H.K., Nagelkerke, L.A.J.1, 2015. Nile perch distribution in south-east Lake Victoria is more strongly driven by abiotic factors, than by prey densities. Hydrobiologia, 10.1007/s10750-015-2237-x.

Cornelissen, I.J.M., Vijverberg, J., van den Beld, A.M., Helmsing, N.R., Verreth, J.A.J., Nagelkerke, L.A.J.l, 2017. Heterogeneity in food-web interactions of fish in the Mwanza Gulf, Lake Victoria: a quantitative stable isotope study. Hydrobiologia, DOI 10.1007/810750-0173297-x.

Culver, D.A., Boucherle, M.M., Bean, D.J., Fletcher, J.W.l, 1985. Biomass of freshwater crustacean zooplankton from length-weight regression. Can. J. Fish. Aquat. Sci. 42, 1380-1390.

Dadebo, E., Mengistou, S., Gebre-Mariam, Z.l, 2005. Feeding habits of the Nile perch, Lates niloticus (L.) (Pisces: Centropomidae) in Lake Chamo, Ethiopia. Ethiop. J. Sci. 28, 61-68.

Davis, A.M., Blanchette, M.L., Pusey, B.J., Jardine, T.D., Pearson, R.G.l, 2012. Gut content and stable isotope analyses provide complementary understanding of ontogenetic dietary shifts and trophic relationships among fishes in a tropical river. Freshw. Biol. 57, 2156-2172.

Dromard, C.R., Bouchon-Navaro, Y., Harmelin-Vivien, M., Bouchon, C.1, 2015. Diversity of trophic niches among herbivorous fishes on a Caribbean reef (Guadeloupe, Lesser Antilles), evidenced by stable isotope and gut content analyses. J. Sea Res. 95, 124-131.

Galarowicz, T.L., Adams, J.A., Wahl, D.H.l, 2006. The influence of prey availability on ontogenetic diet shifts of a juvenile piscivore. Can. J. Fish. Aquat. Sci. 63, 1722-1733.

Garcia-Berthou, E., Moreno-Amich, R.l, 2000. Food of introduced pumpkinseed sunfish: ontogenetic diet shift and seasonal variation. J. Fish Biol. 57, 29-40.

Gee, J.M.l, 1969. A comparison of certain aspects of the biology of Lates niloticus (LINNE) in some East African Lakes. Rev. Zool. Bot. Afr. 80, 244-262.

Goudswaard, K., Witte, F., Wanink, J.H., 2006. The shrimp Caridina nilotica in Lake Victoria (East Africa), before and after the Nile perch increase. Hydrobiologia 563, 31-44.

Grey, J.l, 2001. Ontogeny and dietary specialization in brown trout (Salmo trutta L.) from Loch Ness, Scotland, examined using stable isotopes of carbon and nitrogen. Ecol. Freshw. Fish 10, 168-176.

Hamblyn, E.L.l, 1966. The food and feeding habits of nile perch Lates niloticus (LINNE) (Pisces: Centropomidae). Rev. Zool. Bot. Afr. 75, 128.

Hart, R.C.l, 1980. Embryonic duration and post-embryonic growth rates of the tropical freshwater shrimp Caridina nilotica (Decapoda: Atyidae) under laboratory and experimental field conditions. Freshw. Biol. 10, 297-315.

Hughes, N.F.l, 1986. Changes in the feeding biology of the Nile perch, Lates niloticus (L.) (Pisces: Centropomidae), in Lake Victoria, East Africa since its introduction in 1960, and its impact on the native fish community of the Nyanza Gulf. J. Fish Biol. 29 , 541-548.

Hughes, N.F.l, 1992. Nile perch, Lates niloticus, predation on the freshwater prawn, Caridina nilotica, in the Nyanza Gulf, Lake Victoria, East Africa. Environ. Biol. Fishes 33, 307-309.

Katunzi, E.F.B., Van Densen, W.L.T., Wanink, J.H., Witte, F.l, 2006. Spatial and seasonal patterns in the feeding habits of juvenile Lates niloticus (L.), in the Mwanza Gulf of Lake Victoria. Hydrobiologia 568, 121-133.

Kilham, S.S., Hunte-Brown, M., Verburg, P., Pringle, C., Whiles, M.R., Lips, K.R., Zandona, E., 2009. Challenges for interpreting stable isotope fractionation of carbon and nitrogen in tropical aquatic ecosystems. Verh. der Internat. Ver. für Limn. 30: 749-753.

Kimirei, I.A., Nagelkerken, I., Trommelen, M., Blankers, P., van Hoytema, N., Hoeijmakers, D., Huijbers, C.M., Mgaya, Y.D., Rypel, A.L.l, 2013. What drives ontogenetic niche shifts of fishes in coral reef ecosystems? Ecosystems 16, 783-796.

Kishe-Machumu, M.A., Witte, F., Wanink, J.H., Katunzi, E.F.B.l, 2012. The diet of Nile perch, Lates niloticus (L.) after resurgence of haplochromine cichlids in the Mwanza Gulf of Lake Victoria. Hydrobiologia 682, 111-119.

Kishe-Machumu, M.A., van Rijssel., J.C., Wanink, J.H., Witte, F., 2015. Differential recovery and spatial distribution pattern of haplochromine cichlids in the Mwanza Gulf of Lake Victoria. J. Great Lakes Res. 41, 454-462.

Leuven, R.S.E.W., van den Brink, F.W.B., van der Velde, G.l, 2008. Biometrics and fecundity of the freshwater shrimp, Caridina nilotica (P.Roux, 1833) (Decapoda, Caridea, Atyidae) in the lower Nile river (Egypt). Crustaceana 81, 227-239.

Luczkovich, J.J., Norton, S.F., Gilmore, R.G.l, 1995. The influence of oral anatomy on prey selection during the ontogeny of two percoid fishes, Lagodon rhomboides and Centropomus undecimalis. Environ. Biol. Fishes 44, 79-95. 
McCutchan, J.H., Lewis, W.M., Kendall, C., Mcgrath, C.C., 2003. Variation in trophic shift for stable isotope ratios of carbon, nitrogen, and sulfur. Oikos 102: 378-390.

Mkumbo, O.C., 2002. Assessment and management of Nile perch (Lates niloticus L.) stocks in the Tanzanian waters of Lake Victoria. PhD thesis, University of Hull, Cottingham.

Mkumbo, O.C., Ligtvoet, W.l, 1992. Changes in the diet of Nile perch, Lates niloticus (L.), in the Mwanza Gulf, Lake Victoria. Hydrobiologia 232, 79-83.

Nowak, G.M., Tabor, R.A., Warner, E.J., Freh, K.L., Quinn, T.P.l, 2004. Ontogenetic shifts in habitat and diet of cutthroat trout in Lake Washington, Washington. N. Am. J. Fish. Manage. 24, 624-635.

Ogutu-Ohwayo, R., 1990. Changes in the prey ingested and the variations in the Nile perch and other fish stocks of Lake Kyoga and the northern waters of Lake Victoria (Uganda). J. Fish Biol. 37, 55-63.

Parnell, A., Inger, R., Bearhop, S., Jackson, A.L., 2008. SIAR: Stable isotope analysis in R. Retrieved from: http://Cran.R-Project.Org/Web/Package/Siar.

Peterson, B.J., Fry, B.l, 1987. Stable isotopes in ecosystem studies. Annu. Rev. Ecol. Syst. 18, 293-320.

Post, D.M., 2002. Using stable isotopes to estimate trophic position: models, methods, and assumptions. Ecol. 83: 703-718.

Post, D.M., Layman, C.A., Arrington, D.A., Takimoto, G., Quattrochi, J., Montaña, C.G., 2007. Getting to the fat of the matter: models, methods and assumptions for dealing with lipids in stable isotope analyses. Oecologia 152, 179-189.

R Core Team, 2014. R: A language and environment for statistical computing, R foundation for statistical computing, 2014, Vienna, Austria, http://www.R-project.org.

Schofield, P., Chapman, L.l, 1999. Interactions between Nile perch, Lates niloticus, and other fishes in Lake Nabugabo, Uganda. Environ. Biol. Fishes 55, 343-358.

Talling, J.F.l, 1966. The annual cycle of stratification and phytoplankton growth in Lake Victoria (East Africa). Int. Rev. Gesamt. Hydrobiol. 51, 545-621.

Wainwright, P.C., Richard, B.A.l, 1995. Predicting patterns of prey use from morphology of fishes. Environ. Biol. Fish 44, 97-113.

Werner, E.E., Gilliam, J.F.l, 1984. The ontogenetic niche and species interactions in size-structured populations. Annu. Rev. Ecol. Syst. 15, 393-425.

Winemiller, K.O.l, 1990. Spatial and temporal variation in tropical fish trophic networks. Ecol. Monogr. 60, $331-367$.

Witte, F., Msuku, B.S., Wanink, J.H., Seehausen, O., Katunzi, E.F.B., Goudswaard, P.C., Goldschmidt, T.l, 2000. Recovery of cichlid species in Lake Victoria: an examination of factors leading to differential extinction. Rev. Fish Biol. Fish. 10, 233-241.

Witte, F., van Densen, W.L.T., 1995. Fish stocks and fisheries of Lake Victoria; a handbook for field observations. Samara Publishing Limited, Cardigen.

Witte, F., van Oijen, M.J.P., 1990. Taxonomy, ecology and fishery of Lake Victoria haplochromine trophic groups. Zool. Verh. 262, 1-47.

Witte, F., Wanink, J.H., Kishe-Machumu, M., Mkumbo, O.C., Goudswaard, P.C., Seehausen, O.l, 2007. Differential decline and recovery of haplochromine trophic groups in the Mwanza Gulf of Lake Victoria. Aquat. Ecosyst. Health Manage. 10(4), $416-433$.

Wu, L., Culver, D.l, 1992. Ontogenetic diet shift in Lake Erie age-0 yellow Perch (Perca flavescens): A size-related response to zooplankton density. Can. J. Fish. Aquat. Sci. 42, 1932-1937. 


\section{Appendix A. Supplementary data}

Supplementary data to this article can be found online at https://doi.org/10.1016/j.jglr.2018.08.008.

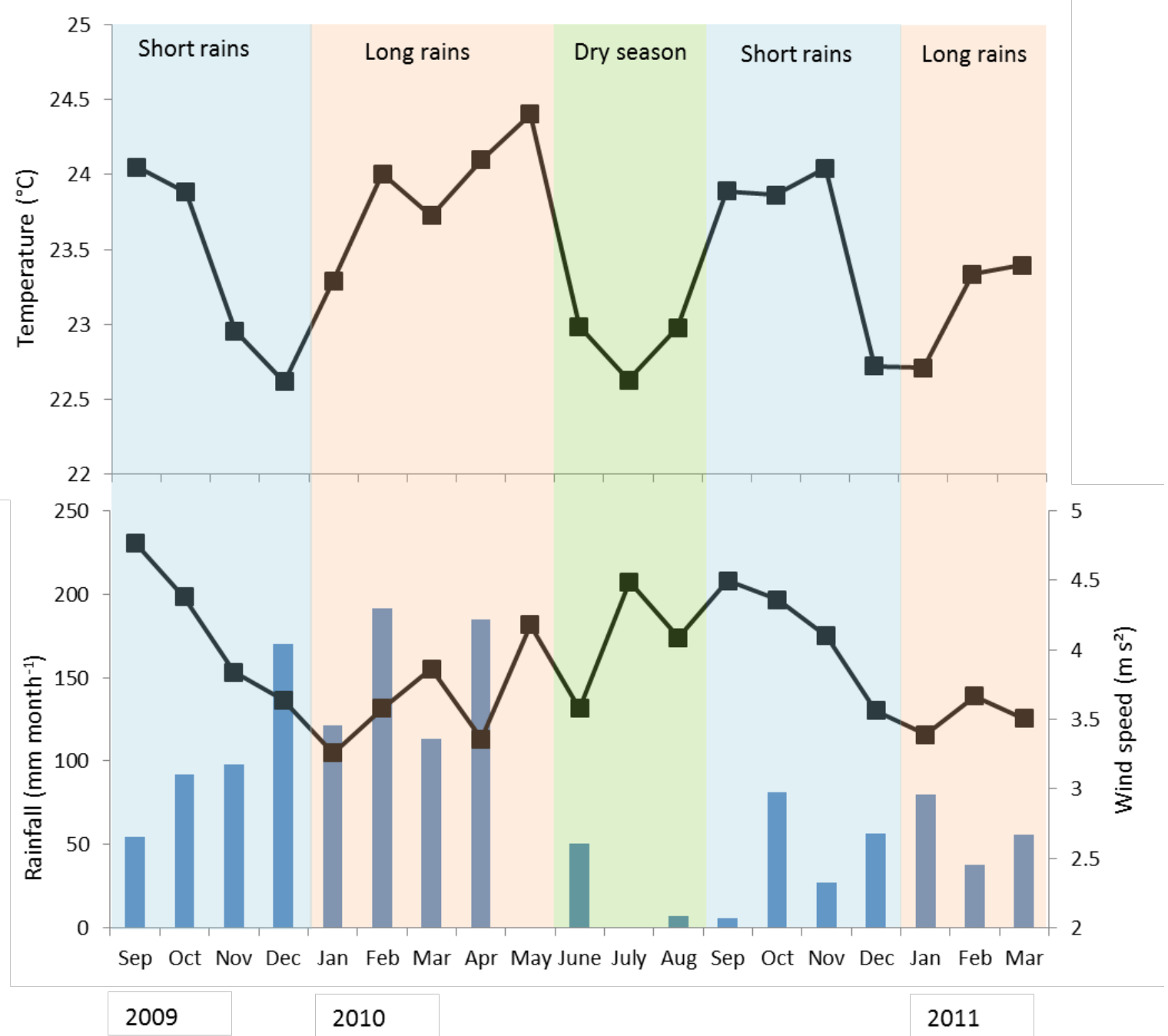

Fig. S1 Monthly weather conditions during the study period from 2009 to 2011 of mean temperature (upper squares), rainfall (histograms) and mean wind speed (lower squares) (Fig. S1, Cornelissen et al., 2017). 
Table S1 Mean relative diet contributions based on stable isotopes and stomach contents. Diet contributions based on stable isotopes with 95\% probability intervals and diet contributions based on stomach contents with $95 \%$ confidence intervals. Diet proportions of $<0.05$ in stomach contents were excluded in the mixing model used to estimate isotope diet contributions.

\begin{tabular}{|c|c|c|c|c|c|c|c|}
\hline \multirow[t]{2}{*}{ Size class } & \multirow[t]{2}{*}{ Resource } & \multicolumn{3}{|c|}{ Isotope diet contribution } & \multicolumn{3}{|c|}{ Stomach diet contribution } \\
\hline & & Mean & Lower CI & Upper CI & Mean & Lower CI & Upper CI \\
\hline \multirow[t]{7}{*}{$<5 \mathrm{~cm}$} & Zooplankton & 0.46 & 0.00 & 0.70 & 0.19 & 0.12 & 0.26 \\
\hline & Caridina nilotica & 0.11 & 0.00 & 0.45 & 0.35 & 0.29 & 0.42 \\
\hline & Haplochromine cichlid & - & - & - & - & - & - \\
\hline & Lates niloticus & - & - & - & - & - & - \\
\hline & Insect larvae & 0.43 & 0.18 & 0.66 & 0.46 & 0.39 & 0.54 \\
\hline & Gastropods & - & - & - & - & - & - \\
\hline & Rastrineobola argentea & - & - & - & - & - & - \\
\hline \multirow[t]{7}{*}{$5-10 \mathrm{~cm}$} & Zooplankton & - & - & - & - & - & - \\
\hline & Caridina nilotica & 0.63 & 0.56 & 0.76 & 0.64 & 0.61 & 0.67 \\
\hline & Haplochromine cichlid & 0.35 & 0.23 & 0.46 & 0.18 & 0.16 & 0.19 \\
\hline & Lates niloticus & - & - & - & $410^{-3}$ & $1.210^{-3}$ & 0.01 \\
\hline & Insect larvae & - & - & - & $4.810^{-3}$ & $1.410^{-3}$ & 0.01 \\
\hline & Gastropods & - & - & - & $5.210^{-4}$ & 0.00 & $1.610^{-3}$ \\
\hline & Rastrineobola argentea & 0.02 & 0.00 & 0.09 & 0.18 & 0.16 & 0.19 \\
\hline \multirow[t]{7}{*}{$10-20 \mathrm{~cm}$} & Zooplankton & - & - & - & - & - & - \\
\hline & Caridina nilotica & 0.55 & 0.49 & 0.59 & 0.60 & 0.58 & 0.61 \\
\hline & Haplochromine cichlid & 0.40 & 0.26 & 0.51 & 0.30 & 0.28 & 0.31 \\
\hline & Lates niloticus & - & - & - & 0.02 & 0.02 & 0.03 \\
\hline & Insect larvae & - & - & - & 0.02 & 0.02 & 0.03 \\
\hline & Gastropods & - & - & - & $3.410^{-3}$ & $1.710^{-3}$ & 0.01 \\
\hline & Rastrineobola argentea & 0.06 & 0.00 & 0.16 & 0.05 & 0.04 & 0.06 \\
\hline \multirow[t]{7}{*}{$20-40 \mathrm{~cm}$} & Zooplankton & - & - & - & - & - & - \\
\hline & Caridina nilotica & 0.37 & 0.28 & 0.44 & 0.12 & 0.10 & 0.15 \\
\hline & Haplochromine cichlid & 0.04 & 0.00 & 0.16 & 0.67 & 0.64 & 0.69 \\
\hline & Lates niloticus & 0.27 & 0.19 & 0.40 & 0.10 & 0.08 & 0.11 \\
\hline & Insect larvae & 0.32 & 0.22 & 0.41 & 0.07 & 0.05 & 0.08 \\
\hline & Gastropods & - & - & - & 0.01 & 0.01 & 0.02 \\
\hline & Rastrineobola argentea & - & - & - & 0.04 & 0.03 & 0.05 \\
\hline \multirow[t]{7}{*}{$>40 \mathrm{~cm}$} & Zooplankton & - & - & - & - & - & - \\
\hline & Caridina nilotica & - & - & - & - & - & - \\
\hline & Haplochromine cichlid & 0.07 & 0.00 & 0.23 & 0.80 & 0.71 & 0.88 \\
\hline & Lates niloticus & 0.93 & 0.77 & 1.00 & 0.17 & 0.09 & 0.25 \\
\hline & Insect larvae & - & - & - & $4.010^{-3}$ & 0.00 & 0.01 \\
\hline & Gastropods & - & - & - & 0.02 & 0.00 & 0.05 \\
\hline & Rastrineobola argentea & - & - & - & 0.01 & $1.010^{-3}$ & 0.02 \\
\hline
\end{tabular}

